IRSTI 06.35.31

\author{
Nawaz Ahmad', Muhammad Noman Ansari², \\ Aamir Feroz Shamsi ${ }^{3}$ \\ ${ }^{1}$ Assistant Professor, e-mail: nawaz.ahmad@iobm.edu.pk \\ ${ }^{2}$ MPhil Scholar, e-mail: std 21634@iobm.edu.pk \\ ${ }^{1,2}$ Institute of Business Management, Pakistan, Karachi \\ ${ }^{3}$ Professor, Shaheed Zulfikar Ali Bhutto Institute of Science and Technology, \\ Pakistan, Karachi, e-mail: aamirfs.personal@gmail.com

\section{FACTORS AFFECTING DIVIDEND PAYOUT: EMPIRICAL INVESTIGATION FROM CEMENT SECTOR OF PAKISTAN}

\begin{abstract}
Dividend policy/payout (DP) is one the areas of finance where extensive research has been conducted to find out the determinants that why firms pay the dividend and what motivates them to share their earnings with shareholders. This situation is termed as a puzzle by researchers. To solve this puzzle, researchers have outlined various financial and non-financial factors. This research is carried out to find the effect of financial factors viz. size, profitability, risk, leverage, and liquidity over the DP of the firms listed on Pakistan Stock Exchange (PSX) in the cement sector. Firms involved in the manufacturing of cement are selected and other firms of the sector are excluded. Data for ten years i.e. from 2009 to 2018 has been extracted from the published annual financial statements of the firms. To verify the relationship between dependent and independent variables, the bivariate correlation has been applied and to find the best-fit regression model, backward multiple regression has been applied. According to the findings from backward multiple regression, profitability and liquidity are the factors that influence the dividend payouts of the firm positively and significantly. Whereas, size, risk, and leverage have failed to show their significance over the dividend payment of the sector.
\end{abstract}

Key words: Dividend policy, dividend payout, dividend payout ratio, firm size.

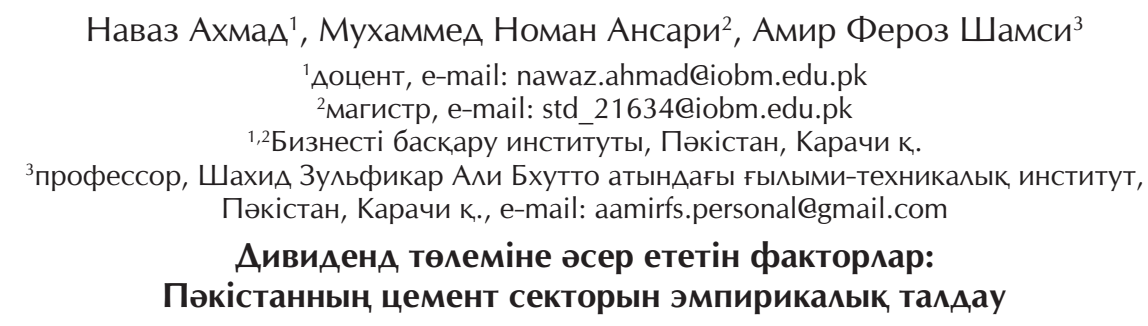

Аивиденатерді төлеу саясаты - бұл фирмалар не себепті дивиденАтер төлейтінін және фирма табысын акционерлермен бөлісу себептерін анықтауға бағытталған ауқымды зерттеулер жүргізілген қаржы салаларының бірі. Зерттеушілер бұл жағАайды ойжұмбақ, деп атайды. Бұл құпияны шешу үшін зерттеушілер түрлі қаржылық және қаржылық емес факторларды анықтауда. Бұл зерттеу Пәкістан қор биржасында тіркелген цемент секторындағы компаниялардың төленген дивидендтерімен салыстырғанАа, қаржы факторларының әсерін, атап айтқанАа: көлемі, кірістілігі, тәуекелдері, мевереджі және өтімАілікті бағалауға арналған. Тек цемент өндіретін фирмалар таңдап алынды, сектордағы басқа фирмалар алынып тасталды. Зерттеу үшін он жылдық, яғни 2009 жылдан 2018 жылға дейінгі, фирмалардың жарияланған жылдық қаржылық, есептерінен алынған деректер пайдаланылды. Тәуелді және тәуелсіз айнымалылардың арасындағы байланысты зерттеу үшін екі өлшемАі корреляция пайдаланылды, сапалы регрессия моделін құру үшін көптік кері регрессия қолданылды. Көптік кері регрессияның нәтижесінде кірістілік 
және өтімділік компанияның дивидендтерін төлеуге оң әсер ететін факторлар екені анықталды. А^, көлем, тәуекел және левередж секторда дивидендтер төлеуге қарағанда маңызды емес коэфффициенттер болып шықты. көлемі.

Түйін сөздер: дивидендтік саясат, дивиленд төлеу, дивиденд төлеу коэфффициенті, фирманың

\author{
Наваз Ахмад ${ }^{1}$, Мухаммед Номан Ансари², Амир Фероз Шамси \\ 'Аоцент, e-mail: nawaz.ahmad@iobm.edu.pk \\ ${ }^{2}$ магистр, e-mail: std 21634@iobm.edu.pk \\ 1,2Институт управления бизнесом, Пакистан, г. Карачи \\ ${ }^{3}$ профессор, Научно-технический институт Шахида Зульфикара Али Бхутто, \\ Пакистан, г. Карачи, e-mail: aamirfs.personalegmail.com \\ Факторы, влияющие на выплату дивидендов: \\ эмпирическое исследование цементного сектора Пакистана
}

\begin{abstract}
Политика выплаты дивидендов - это одна из областей финансов, в которой были проведены обширные исследования для выяснения, почему именно фирмы выплачивают дивиденды и что побуждает их делиться своими доходами с акционерами. Исследователи называют эту ситуацию головоломкой. Аля того чтобы решить эту загадку, исследователи выделили различные финансовые и нефинансовые факторы. Аанное исследование посвящено оценке влияния финансовых факторов, как: размер, прибыльность, риск, Аевередж и ликвидность по сравнению с выплаченными дивидендами компаний, зарегистрированных на Пакистанской фондовой бирже в цементном секторе. Отбираются только фирмы, занимающиеся производством цемента, а другие фрирмы сектора исключаются. В исследовании были использованы данные за десять лет, то есть с 2009 по 2018 год, которые были взяты с опубликованных ежегодных финансовых отчетов фирм. Аля проверки взаимосвязи между зависимыми и независимыми переменными была применена двумерная корреляция, а Аля построения регрессионной модели наилучшего соответствия была применена обратная множественная регрессия. Согласно результатам обратной множественной регрессии, прибыльность и ликвиАность являются факторами, которые положительно и существенно влияют на выплаты дивидендов компании. Также следует отметить, что размер, риск и левередж оказались не значимыми коэффициентами по сравнению с выплатой АивиденАов в секторе.
\end{abstract}

Ключевые слова: политика Аивидендов, выплата АивиденАОв, коэффициент выплаты АивиденАов, размер фирмы.

\section{Introduction}

Dividend payout (DP) is an area of finance on which extensive empirical research has been conducted and yet it is ambiguous that what are the determining factors of DP of the firms (Patra et al., 2012). Funds generated through retaining profits/ earnings will result in more funds available with management for financing the projects which have positive returns as compared to the firm's hurdle rate, i.e. positive NPV, and consequently increases the firm's value and increases its share value (Miller \& Modigliani, 1961). Earnings retained by the firms is also a source of low-cost funds as compared to raising funds from capital markets and obtaining debts (external financings) (Rozeff, 1982). Whereas distributing dividends slashes the resources under control of the managers and resultantly managers have less power (Jensen, 1986). Having all these negative factors related to dividend policy and payout, still, firms pay dividends. It's a puzzle and no obvious reason is available that why firms pay the dividend (Black, 1976)? There are possibilities for managers to believe that shareholders pay the premium for those firms which distribute their earnings as dividends (Easterbrook, 1984). Although, Miller \& Modigliani (1961) made the proposition that dividend has no relevance with the firm or share valuation under the perfect market assumption. But Lintner (1962) and Gordon (1963) argued under imperfect conditions, dividend policy impacts the share price and dividend policy is relevant to the value of a firm. If we ignore the regulatory requirements to pay dividends, then what are the factors with which we can relate the payment of dividend and dividend policy?

For the past many decades, researchers are trying to solve this puzzle. Lintner (1956) was declared by researchers as the first person who tried to uncover the hidden facts about the dividend policy. According to his findings, management tries to smooth the dividend over the years and ties the dividend with long-term sustainable profitability of the firm. His model links the dividend payment to 
long-term target ratio and profitability of the firm.

Several empirical studies have been conducted to gauge the determinants of dividend policy in Pakistan and which model fits the most e.g. Nishat \& Bilgrami (1994) performed the very first empirical analysis of firms listed on Karachi Stock Exchange to find the determinants; Haleem \& Javid (2011) conducted a study on textile, cement, chemicals, and energy sector; Ahmed \& Javid (2008), and Arif \& Akbarshah (2013) analyzed the non-financial sector; Asif, Rasool, \& Kamal (2011) analyzed the effect of leverage on DP whereas Imran (2011) performed an empirical study on the firms listed in the engineering sector. Ali Khan \& Ahmad (2017) analyzed empirically the determinants of DP of Pharmaceuticals firms listed on PSX.

This study aims to add to the existing body of knowledge the significant determinants which influences the DP and dividend policy of Pakistani Firms listed on PSX under the sector of Cement. As per the authors' knowledge, no attempt was made in this sector for determining the factors.

The objective of this study is to find out the impact of selected factors, chalked out from the available literature, on the DP decisions taken by Cement Sector firms listed on PSX.

The study will empirically analyze the impact of Firm Size, Profitability, Risk, Leverage, and Liquidity over DP decisions of the Cement firms listed on PSX.

Following hypotheses are constructed to find the impact of the firm's size, profitability, risk, leverage, and liquidity of the firm over DP.

H1: Size of the firm does not have any impact on DP.

$\mathrm{H} 2$ : Profitability of the firm does not have any impact on DP.

H3: Risk of future cash flows to the shareholders does not have any impact on DP.

H4: Leverage of the firm does not have any impact on DP.

H5: Liquidity of the firm does not have any impact on DP.

\section{Literature review}

Lintner (1956) was among the predecessors who worked to find out that what are the factors that induce the firms to pay the dividend? In order to uncover this dividend mystery, he conducted a survey of senior managers of US firms who were responsible for making the dividend decision. He wanted to learn from their perception and beliefs that what factors influence their dividend policy decisions (Baker et al., 2001). After a review of academic and non-academic literature and corporate financial policies, Lintner came up with fifteen factors and characteristics that might have an impact on the dividend policy of the firms. He selected 28 firms and this sample was not statistically selected, but rather purposefully selected to encircle a wide variety of firms with various situations and different characteristics. He interviewed the manager and found that changes in dividend follow only those patterns of changes in earnings that are sustainable over long-run. He found that managers tended to avoid making changes in dividend rates that could be reversed in the coming years. Managers believe that shareholders prefer a stable rate of dividend and pay a premium for stability and steady growth. According to his findings, managers avoid dividend cuts and try to smooth the dividend over the longterm. He concluded that firms set a long-term dividend payout ratio (DPR) or target ratio and make a regular partial adjustment in the payout ratio in order to catch-up the target ratio. According to his findings, for maintaining target DPR management plans in advance to coupe its liquidity shortages at the time making dividend payments. He found that the firms with ample investment opportunities consider making investments in projects if they have enough funds available after paying the dividend. If the firms decide to go on leverage, they will reexamine the projects with respect to their cost of debt. He developed a mathematical model and incorporates the findings of his survey in it. His work has been considered a seminal work and established the basis on which modern understanding of dividend policy is built (Brav et al., 2005).

Researchers have positively correlated the size and profitability of the firm with the dividend payout policy and suggest that larger firms pay dividends regularly. Fama \& French (2001) conducted a study to find out which firms pay dividends and found that larger firms with more profitability pay more dividends than those firms which are smaller in size and have less profitability.

Crutchley \& Hansen (1989) conducted an analysis to test the impact of agency costs. He argues that firm size negatively associated with managerial ownership. He founds that larger firms' managers more rely on debts and dividends because their liquidity cost and flotation cost are lower and economical for them.

Redding (1997) presented a model which positively tested the relationship between the DP and size of the firm. He found that firms with large size have more liquidity to pay dividends. Size of 
firm, profitability, and liquidity all the factors which affect the DP. Larger firms have more easy access to capital and debt markets. Therefore, they can afford to pay dividends regularly because they can easily cover their liquidity and investment requirements through easy access to the markets.

Al-Twaijry (2007) performed a statistical analysis of firms listed over Kuala Lumpur Stock Exchange in order to find the variables which affect the DP. His findings suggest that the leverage of the firms is negatively associated with DPs whereas size has no significant effect on DP. As per his findings, net earnings of the firms have a less strong association with DP. He also discovered that cash per share (liquidity) has a positive effect of dividend per share and DPR.

Jabbouri (2016) conducted a study to identify the factors affecting DP in the Middle East and North African Countries. He revealed that DP has a significant and positive association with the firm's size, current profits, and liquidity. Among the negatively correlated factors, leverage, free cash flow and the state of the economy country contribute their part. However, future profits and the pattern of past dividend fell short of showing any impact.

Mehta (2012) performed an empirical analysis of firms (except bank and investment concerns) listed over the Abu Dhabi Stock Exchange in order to find out the variables the play role in determining the dividend policy. His investigations revealed that the size of the firm has a significantly positive impact on the DP whereas risk has a significant negative impact over the DP. Profitability, leverage, and liquidity are among ineffective factors that demonstrate no significance over the policy. In order to evaluate the impact of risk, the author used price to earnings ratio (PE ratio).

Aivazian, Booth, \& Cleary (2003) conducted an empirical study to compare the sample firms from eight emerging markets with 99 firms in the United States. The study reveals the firms in the US and the emerging markets, profitability has a positive significant effect over the dividend policy, however, the leverage has a negative significant effect and risk has an insignificant impact on the dividend policy.

Kania \& Bacon (2005) in his study reveals that profitability, risk, liquidity, and leverage all are negatively correlated with DP whereas profitability growth has a positive association.

Moradi, Salehi, \& Honarmand (2010) concluded from their research conducted over all listed firms of Tehran Stock Exchange that firms with high leverage have a significant and positive relationship between leverage and dividend policy whereas firms with lower debt to equity ratio have a significant and negative relationship between and dividend policy. The author also revealed that profitability has a direct and significant relationship with DPs. Beta and price earning ratio have significant negative relationships with dividend policy. While the size of the firm has no impact on DP.

Patra et al. (2012) performed a study to find the determinants of dividend policy adopted by the firms listed on the Athens Stock Exchange (ASE). Their study disclosed that the DP decision of the firms in Athens is positively affected by firm size, profitability and liquidity whereas investment opportunities, leverage, and business risk impacts negatively.

In a study conducted by Khan, Ali, Batool, \& Ali (2017) to find the major indicators of dividend policy of private commercial banks of Pakistan, the authors found that banks with healthy profits and high leverage pays less dividend.

Tahir \& Mushtaq (2016) studies the firms of the oil and gas sector listed over the Karachi Stock Exchange (KSE) to find the determinants of DP of these firms. Their study revealed that financial leverage has a negative significant impact on the DP along with business risk and ownership structure. According to their findings, firms in governmental control pay less dividend as compared to private sector firms. Profitability, sales growth, and firm size contribute positively while deciding the DPR. Liquidity and investment opportunities found as less significant factors.

M.N.Khan, Naeem, \& Salman (2016) performed an empirical study over the firms in the textile sector of Pakistan listed over PSX. Their study revealed that higher profitability firms pay fewer dividends. Leverage also has a negative relationship with DP. Similar is the case with liquidity whereas firms' size and risk have no impact on the DPR.

Ahmed \& Javid (2009) conducted an empirical analysis of non-financial firms listed over KSE to find that the firms follow stable DPR and the factors affecting DP. They match the behaviour of Pakistani firms with the findings of Lintner (1956) and they found that the firms' behaviour do not match the Lintner's finding and firms do not smooth dividends. Their finding suggests that firms with higher profitability, higher insider shareholding, and higher market liquidity pay more dividends whereas larger firm size and higher investment opportunities impact adversely while drafting the policy. The growth of the firms found to be neutral while deciding DP.

Ali Khan \& Ahmad (2017) conducted empirical research to reveal the factors affecting the DP of the 
firms listed on PSX in the pharmaceuticals sector. Their study uncovers that profitability and audit type i.e. audit performed by the big four firms will have a positive and significant impact on the DP whereas growth opportunities, risk and liquidity significantly also impact the DP but in a negative manner. However, leverage, taxation, and the size of the firm failed to show any significance over the DP.

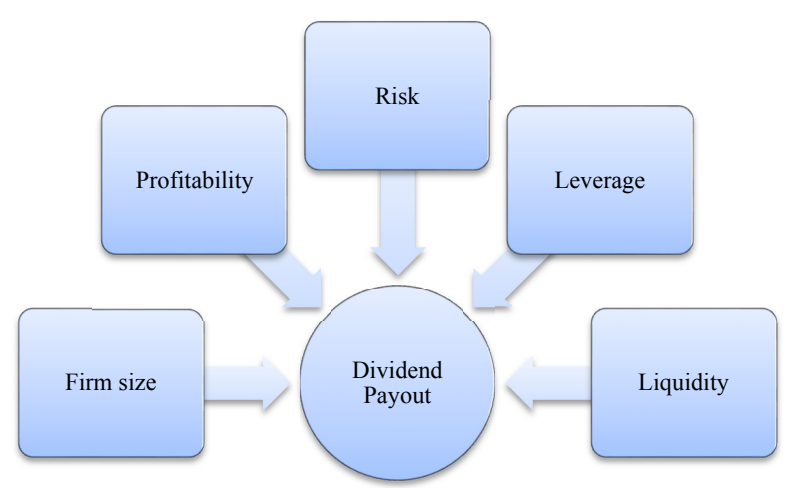

Figure 1 - Factors effecting Dividend Payout Note - compiled by authors

From the above literature, it is evident that widespread empirical work has been done in the area of DP by academics in different regions of the world and covered different types of firms. From the literature, it is outlined that the profitability, growth opportunities, firm size, leverage, risk, liquidity, ownership structures are the common factors which impact the DP of the firms. However, their impact is not absolute in all over the world and in all sectors but varies with legal and institutional frameworks and regional and industrial attributes.

From the literature, it is also apparent that several studies have been performed in Pakistan to ascertain the determinants of DP but to the best of our knowledge, no study has been carried out to find the factors of the firms listed in the cement sector of PSX. Therefore, to fill this gap this study attempts to analyze the impact of firm size, profitability, risk, liquidity, and leverage on the DPR of the cement sector of PSX.

\section{Methodology}

The study is performed by using the secondary data extracted from the financial statements of the cement sector firms available over their websites. Selected financial information of 10 years, i.e. from 2009 to 2018 has been compiled from these statements for achieving study objectives.

From the available empirical literature, the following independent variables have been selected to find their impact on the firms' DP:

Variables of the Research

Firms listed on the PSX in Cement sector and producing cement are included in this study. Firms that are defaulter or whose trading is suspended are not considered. Firms whose ten years of data is not available are excluded from the analysis. Firms that do not produce cement are also not included in the analysis.

Table 1 - Independent and Dependent Variables

\begin{tabular}{|c|c|c|}
\hline Independent variable & Symbol & Formula \\
\hline Firm Size & NLTA & Natural Log of Total Asset \\
\hline Profitability & ROA & Net Earnings / Total Asset \\
\hline Risk & PER & Market Price per Share / Earning per share \\
\hline Leverage & LEV & (Short-Term Liabilities + Long-Term Liabilities) / Total Assets \\
\hline Liquidity & CR & Current Assets / Current Liabilities \\
\hline Dependent Variables & Symbol & Cash Dividend / Net Earning *100 \\
\hline Dividend Payout Ratio & DPR & \\
\hline $\begin{array}{c}\text { Source: Financial Management by } \\
\text { Brigham, 13th edition }\end{array}$ & & \\
\hline
\end{tabular}




\section{Sample and Sampling Technique}

The study is conducted on 15 firms of the cement sector listed on PSX. There are 21 firms listed in this sector out of these, two are in defaulter segment, one is ready-mix concrete firm, one is involved in real estate business, and remaining 17 firms are cement manufacturer. Out of these seventeen firms, one firm has acquired the other firm of the sector due to which both firms are not included in the sample (Table 2). As the acquisition of the firm results in a drastic change in the value of assets, liabilities, and profits in the year of acquisition and this may distort our analysis. The reason for choosing the cement sector for this study is that cement is among the sectors which are going through a robust growth phase. There are 24 units operating in the country right now with an installed annual capacity of almost 49.4 million tons and next few year 23.4 million tons annual capacity will be added by $50 \%$ of the firms. The profitability is exceptional of this industry. Average gross profit to sales ratio for the last five years is around 33\% which is more than double as compared to the manufacturing sector's overall average (SBP 3rd Quarterly Review 2017-18, 2018).

Table 2 - Cement Sector Firms in PSX

\begin{tabular}{|c|c|c|}
\hline S.no & PSX Symbol & Firm title \\
\hline \multicolumn{3}{|c|}{ Cement Manufacturers (Sample) } \\
\hline 1 & ACPL & Attock Cement Pak Ltd \\
\hline 2 & $\mathrm{CHCC}$ & Cherat Cement Co. Ltd \\
\hline 3 & DCL & Dewan Cement Limited \\
\hline 4 & DGKC & D.G. Khan Cement Company Limited \\
\hline 5 & DNCC & Dandot Cement Co. Ltd \\
\hline 6 & FLYNG & Flying Cement Co.Ltd Ltd \\
\hline 7 & FECTEC & Fecto Cement Co.Ltd \\
\hline 8 & FCCL & Fauji Cement Co.Ltd \\
\hline 9 & GWCL & Gharibwal Cement Co.Ltd \\
\hline 10 & $\mathrm{KOHC}$ & Kohat Cement Co.Ltd \\
\hline 11 & LUCK & Lucky Cement Limited \\
\hline 12 & MLCF & Maple Leaf Cement Factory Ltd \\
\hline 13 & POWER & Power Cement Ltd \\
\hline 14 & PIOC & Pioneer Cement Ltd \\
\hline 15 & THCCL & Thatta Cement Co.Ltd \\
\hline \multicolumn{3}{|c|}{ Defaulter Firm } \\
\hline 16 & ZELP & Zeal Pak Cement Factory Ltd \\
\hline \multirow[t]{2}{*}{17} & DBCI & Dadabhoy Cement Industries Ltd \\
\hline & Ready-Mix Concrete Firm & \\
\hline 18 & SMCPL & Safe-Mix Concrete Ltd \\
\hline \multicolumn{3}{|c|}{ Real Estate Firm } \\
\hline 19 & JVDC & Jevandon Corporation Ltd \\
\hline \multicolumn{3}{|c|}{ Merged Firm } \\
\hline 20 & BWCL & Bestway Cement Ltd. \\
\hline 21 & LPCL & Larfarge Pakistan Cement Ltd \\
\hline \multicolumn{3}{|c|}{ Source: Pakistan Stock Exchange } \\
\hline
\end{tabular}




\section{Results and discussion}

\section{Descriptive Analysis}

From the below Table 3, it is evident that the data is not normally distributed, hence the null hypothesis that the data is normally distributed is rejected. Detailed analysis is given below:

\section{Dividend Payout}

DPR has a mean of $19.112 \%$ with standard deviation (SD) $23.663 \%$. This indicates that the firms under discussion pay $19.10 \%$ of their earnings as dividend and retain $80.90 \%$ of their earnings on average. The SD indicates that the DPR varies at $\pm 4.552 \%$ across the sector on average.
Size

Size of the firm has a mean of 10.099 and SD is 0.447 indicates that the firms' size does not vary too much in the sector.

Profitability

The profitability of the firm has a mean value of 0.06 and SD 0.097 indicates that the industry's average return is $6 \%$ over their total assets with a variation of $9.7 \%$.

Risk

With mean value 20.472 and SD 170.426 indicates that the firms have 20 times more market price than their earnings, have huge variations of 170 times more market price over earnings.

Table 3 - Descriptive Statistics

\begin{tabular}{|c|c|c|c|c|c|c|}
\hline & Mean & Std. Dev. & Skewness & Kurtosis & Jarque-Bera (JB) & Probability \\
\hline Dividend Payout Ratio & 19.112 & 23.663 & 0.992 & 3.037 & 24.605 & 0.000 \\
\hline Size & 10.099 & 0.447 & 0.084 & 2.180 & 4.377 & 0.112 \\
\hline Profitability & 0.060 & 0.097 & -0.442 & 2.826 & 5.068 & 0.079 \\
\hline Risk & 20.472 & 170.426 & 12.021 & 146.347 & 132040.60 & 0.000 \\
\hline Leverage & 0.525 & 0.302 & 2.038 & 8.281 & 278.110 & 0.000 \\
\hline Liquidity & 1.389 & 1.486 & 4.073 & 30.333 & 5084.057 & 0.000 \\
\hline
\end{tabular}

\section{Leverage}

Leverage has a mean value of 0.525 and $\mathrm{SD}$ value of 0.302 depicting that the average 52.50 assets of the firms are financed through debt with deviation from mean is $30.20 \%$.

\section{Liquidity}

Liquidity has a mean value of 1.389 and SD value of 1.486 meaning that the firms have 1.389 times more current assets than current liabilities with an average variation of 1.486 times.

\section{Inferential Analysis \\ Bivariate Correlation}

To outline the relationship and its significance between independent and dependent variables, a bivariate correlation test is performed. It also finds out multicollinearity between independent variables. Since data is not normal, therefore, Spearman's rho correlation is performed, which is a non-parametric correlation. The test was performed in order to determine whether any correlation exists between DPR and firm size, profitability, risk, leverage and/or liquidity. It also investigates the relationship between the explanatory variables (for results see Table 4). A two-tailed test of significance indicates that:

Table 4 - Bivariate Correlation

\begin{tabular}{|c|c|c|c|c|c|c|c|}
\hline \multicolumn{2}{|c|}{} & $\begin{array}{c}\text { Dividend } \\
\text { Payout } \\
\text { Ratio }\end{array}$ & Size & Profitability & Risk & Leverage & Liquidity \\
\hline \multirow{2}{*}{$\begin{array}{c}\text { Dividend_ } \\
\text { Payout_Ratio }\end{array}$} & $\begin{array}{c}\text { Pearson } \\
\text { Correlation }\end{array}$ & 1 & $.271^{* *}$ & $.739^{* *}$ & $.299^{* *}$ & $-.668^{* *}$ & $.681^{* *}$ \\
\cline { 2 - 9 } & Sig. (2-tailed) & & .001 & .000 & .000 & .000 & .000 \\
\cline { 2 - 9 } & $\mathrm{N}$ & 150 & 150 & 150 & 150 & 150 & 150 \\
\hline
\end{tabular}


Continuation of table 4

\begin{tabular}{|c|c|c|c|c|c|c|c|}
\hline \multirow{3}{*}{ Size } & $\begin{array}{c}\text { Pearson } \\
\text { Correlation }\end{array}$ & $.271^{* *}$ & 1 & $.241^{* *}$ & $.340^{* *}$ & $-.354^{* *}$ & $.304^{* *}$ \\
\hline & Sig. (2-tailed) & .001 & & .000 & .000 & .000 & .000 \\
\hline & $\mathrm{N}$ & 150 & 150 & 150 & 150 & 150 & 150 \\
\hline \multirow{3}{*}{ Profitability } & $\begin{array}{c}\text { Pearson } \\
\text { Correlation }\end{array}$ & $.739^{* *}$ & $.241^{* *}$ & 1 & $.338^{* *}$ &.$-750^{* *}$ & $.736^{* *}$ \\
\hline & Sig. (2-tailed) & .000 & .000 & & .000 & .000 & .000 \\
\hline & $\mathrm{N}$ & 150 & 150 & 150 & 150 & 150 & 150 \\
\hline \multirow{3}{*}{ Risk } & $\begin{array}{c}\text { Pearson } \\
\text { Correlation }\end{array}$ & $.299^{* *}$ & $.340^{* *}$ & $.338^{* *}$ & 1 & $-.391^{* *}$ & $.417^{* *}$ \\
\hline & Sig. (2-tailed) & .000 & .000 & .000 & & .000 & .000 \\
\hline & $\mathrm{N}$ & 150 & 150 & 150 & 150 & 150 & 150 \\
\hline \multirow{3}{*}{ Leverage } & $\begin{array}{c}\text { Pearson } \\
\text { Correlation }\end{array}$ & $-.668^{* *}$ & $-.354^{* *}$ & $-.750^{* *}$ & $-.391^{* *}$ & 1 & $-.779^{* *}$ \\
\hline & Sig. (2-tailed) & .000 & .000 & .000 & .000 & & .000 \\
\hline & $\mathrm{N}$ & 150 & 150 & 150 & 150 & 150 & 150 \\
\hline \multirow{3}{*}{ Liquidity } & $\begin{array}{c}\text { Pearson } \\
\text { Correlation }\end{array}$ & $.681^{* *}$ & $.304^{* *}$ & $.736^{* *}$ & $.417^{* *}$ & $-.779^{* *}$ & 1 \\
\hline & Sig. (2-tailed) & .000 & .000 & .000 & .000 & .000 & \\
\hline & $\mathrm{N}$ & 150 & 150 & 150 & 150 & 150 & 150 \\
\hline \multicolumn{8}{|c|}{ **. Correlation is significant at the 0.01 level (2-tailed) } \\
\hline
\end{tabular}

1. There is a positive and significant relationship between DPR and profitability.

2. There is a negative significant relationship between DPR and leverage.

3. Liquidity shows a strong and significant positive relationship with DPR.

4. Whereas the size and risk of firms do not have any strong association with DPR.

Further, it is evident from the results that there is a correlation between independent variables:

1. Profitability is negatively and significantly correlated with leverage and positively significant correlation with liquidity.

2. Leverage has a negative and significant correlation with liquidity.

This means that the data has a multicollinearity problem and this need to be investigated using linear regression.

Linear Regression for Verifying Multicollinearity

In order to confirm the multicollinearity identified in bivariate correlation among the profitability, leverage, and liquidity; linear regression has been performed. It is evident from the results in Table 5, Table 6 and Table 7 that the value of VIF is in the acceptable limit, i.e. VIF $<10$, therefore, no problem of multicollinearity exist among the independent variables.

Table 5 - Linear Regression for Multicollinearity between leverage and liquidity

\begin{tabular}{|c|c|c|c|}
\hline \multicolumn{3}{|c|}{ Coefficients $^{\mathrm{a}}$} \\
\hline \multicolumn{3}{|c|}{$\begin{array}{c}\text { Model } \\
\text { Tolerance }\end{array}$} & Collinearity Statistics \\
\cline { 2 - 4 } & VIF & \\
\hline \multirow{2}{*}{1} & Leverage & .770 & 1.299 \\
\cline { 2 - 4 } & Liquidity & .770 & 1.299 \\
\hline \multicolumn{3}{|c|}{ a. Dependent Variable: Profitability } \\
\hline
\end{tabular}

Table 6 - Linear Regression for Multicollinearity between liquidity and profitability

\begin{tabular}{|c|c|c|c|}
\hline \multicolumn{4}{|c|}{ Coefficients $^{\mathrm{a}}$} \\
\hline \multirow{2}{*}{\multicolumn{2}{|c|}{$\begin{array}{l}\text { Model } \\
\text { Tolerance }\end{array}$}} & \multicolumn{2}{|c|}{ Collinearity Statistics } \\
\hline & & VIF & \\
\hline \multirow{2}{*}{1} & Liquidity & .740 & 1.351 \\
\hline & Profitability & .740 & 1.351 \\
\hline \multicolumn{4}{|c|}{ a. Dependent Variable: Leverage } \\
\hline
\end{tabular}


Table 7 - Linear Regression for Multicollinearity between profitability and Leverage

\begin{tabular}{|c|c|c|c|}
\hline \multicolumn{4}{|c|}{ Coefficients $^{\mathrm{a}}$} \\
\hline \multirow{2}{*}{\multicolumn{2}{|c|}{$\begin{array}{c}\text { Model } \\
\text { Tolerance }\end{array}$}} & \multicolumn{2}{|c|}{ Collinearity Statistics } \\
\hline & & VIF & \\
\hline \multirow{2}{*}{1} & Profitability & .389 & 2.570 \\
\hline & Leverage & .389 & 2.570 \\
\hline \multicolumn{4}{|c|}{ a. Dependent Variable: Liquidity } \\
\hline
\end{tabular}

\section{Backward Multiple Regression}

Backward multiple regression analysis has been performed to find out which independent variables best describes the DP of the firm.

Table 8 results suggest that with all independent variables present in the model the value of adjusted $\mathrm{R}$ square is 0.386 , which means that the descriptive power of the model is $38.60 \%$. After removing insignificant variables; in this case, these variable are risk, leverage, size of the firm; the final model descriptive power increased to $39.10 \%$.

From the Analysis of Variance (ANOVA) in Table 9, it is evident that the elimination of insignificant and irrelevant independent variables has resulted in an increase in the value of ' $F$ ' from 19.764 to 48.776 with a significance value less than 0.05 .

From the analysis of Table 10, it is evident that model no. 4 is the final model which suggests that if independent variables were not present then cement sector firms would be to pay $7.895 \%$ of its earnings as a dividend with a confidence interval of $99.99 \%$. Whereas every $1 \%$ increase in net earnings over total assets would enhance the dividend payment by $131.559 \%$. The liquidity of the firms has a positive impact on the dividend payment and every $1 \%$ increase in the current ratio would increase the dividend payment by $2.410 \%$. Therefore, the final equation is:

$$
\mathrm{DPR}=7.895+131.559(\mathrm{ROA})+2.410(\mathrm{CR})
$$

Table 8 - Model Summary

\begin{tabular}{|c|c|c|c|c|}
\hline \multicolumn{6}{|c|}{ Model Summary } \\
\hline Model & $\mathrm{R}$ & R Square & $\begin{array}{c}\text { Adjusted } \\
\text { R Square }\end{array}$ & $\begin{array}{c}\text { Std. Error } \\
\text { of the } \\
\text { Estimate }\end{array}$ \\
\hline 1 & $.638^{\mathrm{a}}$ & .407 & .386 & 18.53639 \\
\hline 2 & $.638^{\mathrm{b}}$ & .407 & .39 & 18.47711 \\
\hline 3 & $.635^{\mathrm{c}}$ & .403 & .391 & 18.46485 \\
\hline 4 & $.632^{\mathrm{d}}$ & .399 & .391 & 18.47061 \\
\hline a. Predictors: (Constant), CR,PER,NLTA,ROA,LEV \\
\hline \multicolumn{5}{|c|}{ b. Predictors: (Constant), CR, NLTA,ROA,LEV } \\
\hline \multicolumn{5}{|c|}{ c. Predictors: (Constant), CR, NLTA,ROA } \\
\hline \multicolumn{6}{|c|}{} \\
\hline
\end{tabular}

Table 9 - Anova Table

\begin{tabular}{|c|c|c|c|c|c|c|}
\hline \multicolumn{2}{|c|}{ Model } & Sum of Squares & df & Mean Square & $\mathrm{F}$ & Sig. \\
\hline \multirow{3}{*}{1} & Regression & 33953.846 & 5 & 6790.769 & 19.764 & $.000^{\mathrm{b}}$ \\
\hline & Residual & 49478.080 & 144 & 343.598 & & \\
\hline & Total & 83431.926 & 149 & & & \\
\hline \multirow{3}{*}{2} & Regression & 33928.388 & 4 & 8482.097 & 24.845 & $.000^{\mathrm{c}}$ \\
\hline & Residual & 49503.537 & 145 & 341.404 & & \\
\hline & Total & 83431.926 & 149 & & & \\
\hline \multirow{3}{*}{3} & Regression & 33653.137 & 3 & 11217.712 & 32.901 & $.000^{\mathrm{d}}$ \\
\hline & Residual & 49778.789 & 146 & 340.951 & & \\
\hline & Total & 83431.926 & 149 & & & \\
\hline \multirow{3}{*}{4} & Regression & 33280.924 & 2 & 16640.462 & 48.776 & $.000^{\mathrm{e}}$ \\
\hline & Residual & 50151.001 & 147 & 341.163 & & \\
\hline & Total & 83431.926 & 149 & & & \\
\hline \multicolumn{7}{|c|}{ a. Dependent Variable: DPR } \\
\hline \multicolumn{7}{|c|}{ b. Predictors: (Constant), CR, PER, NLTA, ROA, LEV } \\
\hline \multicolumn{7}{|c|}{ c. Predictors: (Constant), CR, NLTA, ROA, LEV } \\
\hline \multicolumn{7}{|c|}{ d. Predictors: (Constant), CR, NLTA, ROA } \\
\hline \multicolumn{7}{|c|}{ e. Predictors: (Constant), CR, ROA } \\
\hline
\end{tabular}


Table 10 - Coefficients

\begin{tabular}{|c|c|c|c|c|c|c|}
\hline \multirow{2}{*}{\multicolumn{2}{|c|}{$\begin{array}{l}\text { Model } \\
\text { B }\end{array}$}} & \multicolumn{2}{|c|}{ Unstandardized Coefficients } & \multirow{3}{*}{$\begin{array}{c}\text { Standardized } \\
\text { Coefficients }\end{array}$} & \multirow{3}{*}{$\begin{array}{c}\mathrm{t} \\
-1.046 \\
\end{array}$} & \multirow{3}{*}{$\begin{array}{l}\text { Sig. } \\
.297 \\
\end{array}$} \\
\hline & & \multirow{2}{*}{$\begin{array}{c}\text { Std. Error } \\
-42.880\end{array}$} & \multirow{2}{*}{$\begin{array}{c}\text { Beta } \\
41.005 \\
\end{array}$} & & & \\
\hline \multirow{6}{*}{1} & (Constant) & & & & & \\
\hline & Firm Size & 4.600 & 3.876 & .087 & 1.187 & .237 \\
\hline & Profitability & 144.323 & 26.162 & .593 & 5.517 & .000 \\
\hline & Risk & -.002 & .009 & -.018 & -.272 & .786 \\
\hline & Leverage & 7.297 & 8.660 & .093 & .843 & .401 \\
\hline & Liquidity & 2.248 & 1.221 & .141 & 1.841 & .068 \\
\hline \multirow{5}{*}{2} & (Constant) & -45.208 & 39.975 & & -1.131 & .260 \\
\hline & Firm Size & 4.803 & 3.791 & .091 & 1.267 & .207 \\
\hline & Profitability & 145.155 & 25.900 & .597 & 5.605 & .000 \\
\hline & Leverage & 7.659 & 8.530 & .098 & .898 & .371 \\
\hline & Liquidity & 2.239 & 1.217 & .141 & 1.839 & .068 \\
\hline \multirow{4}{*}{3} & (Constant) & -29.666 & 36.010 & & -.824 & .411 \\
\hline & Firm Size & 3.773 & 3.611 & .071 & 1.045 & .298 \\
\hline & Profitability & 128.691 & 18.279 & .529 & 7.040 & .000 \\
\hline & Liquidity & 2.141 & 1.211 & .134 & 1.767 & .079 \\
\hline \multirow{3}{*}{4} & (Constant) & 7.895 & 2.082 & & 3.792 & .000 \\
\hline & Profitability & 131.559 & 18.077 & .541 & 7.278 & .000 \\
\hline & Liquidity & 2.410 & 1.184 & .151 & 2.036 & .044 \\
\hline \multicolumn{7}{|c|}{ a. Dependent Variable: DPR } \\
\hline
\end{tabular}

Hypotheses Assessment Summary

Hypothesis 1

Null hypothesis 1 has been retained with reference to the above analysis which depicts that the firm size represented by the natural log of total assets has no effect on DPR. Firm size is termed as insignificant because it has t-value of 1.045 with sig value above 0.05 i.e. 0.298 in model 3 of Table 10. This means that the DP of the cement industry firms has no impact on the size of the firms. It conforms with the finding of Al-Twaijry (2007), Moradi, Salehi, \& Honarmand (2010); M. N. Khan, Naeem, \& Salman (2016); and Ali Khan \& Ahmad (2017).

Hypothesis 2

Profitability, represented by Return On Assets (ROA), is among the variables that are determinants of DP of the cement industry. It shows its positive significance with sig value less than 0.05 and $t$ value 7.278 in model 4 of Table 10. Therefore, null hypothesis 2 has been failed to be retained and it is rejected. It is the most significant factor that impacts the DP and it is in line with the findings of Redding (1997), Aivazian, Booth, \& Cleary (2003), Kania
\& Bacon (2005), Ahmed \& Javid (2009), Moradi, Salehi, \& Honarmand (2010), Patra et al. (2012), Jabbouri (2016), Tahir \& Mushtaq (2016), and Ali Khan \& Ahmad (2017).

\section{Hypothesis 3}

Null hypothesis 3 has been retained due to the insignificant nature of the risk associated with the firm's future cash flows to its shareholders, represented by the PE ratio. With $t$ value 0.272 and sig value 0.786 in model 1 of Table 10 is the first variable eliminated in backward regression due to its most irrelevant behaviour. Firms in the cement industry have no attention towards risk while considering DPs. This finding is in conformity with the findings of Aivazian, Booth, \& Cleary (2003), and M. N. Khan, Naeem, \& Salman (2016).

\section{Hypothesis 4}

Leverage, represented by total debt to total asset, has failed to show its association with DPR with $\mathrm{t}$ value below 2 and sig value above 0.05 in model 2 of Table 10. Therefore, null hypothesis 4 has been retained. This can be interpreted as the cement sector firms' DP is neutral from the debt position of the firms. This result is in accordance with the 
results of Ho (2003), Mehta (2012), and Ali Khan \& Ahmad (2017).

Hypothesis 5

Liquidity, represented by the current ratio, is one of the variables that have a significant positive impact on the dividend payout policy of the firms of the cement industry. This means that the null hypothesis 5 has been rejected with $\mathrm{t}$ value more than 2 and sig value less than 0.05 . This is in line with the findings Ho (2003), Al-Twaijry (2007), Patra et al. (2012), and Jabbouri (2016).

\section{Conclusion}

This research was conducted with the objective to find the determinants of DP of the firms listed over PSX in the Cement Sector. Ten-year data of 15 cement firms i.e. 150 firm years were analyzed to find the determinants. From the literature review, it is concluded that the dependent variable for this study is DPR and independent variables include size, profitability, risk, leverage, and liquidity of the firm. A bivariate correlation was applied to determine the relationship between dependent and independent variables, and check multicollinearity among independent variables. In order to arrive at the final equation, backward multiple regression was used.

From the investigations, it is revealed that the profitability and liquidity are the factors that impact significantly and positively the DP of the sector. Profitability is the factor which has a high impact over the dependent variable as compared to liquidity. This implies that the firms that are more profitable and have more liquidity pay more dividends as compared to a firm with less profitability and liquidity constraints. These variables are $39.10 \%$ responsible for explaining the variable in the dividend payout policy. It is also revealed that the size of the firm has no significant association with dividend payments. Similar is the case with leverage and risk, which means that the cement sector firms pay dividend irrespective of their size and debt structure. Furthermore, the cement sector firms' DP is not affected by the firm's share prices variations with respect to its earnings.

This study will add to the literature about the detrimental factors that are responsible for the dividend payout policy of cement sector of PSX. This will help the investors in making an investment decision in this sector, which is among the biggest and capital-intensive sector of the economy and directly involved in the growth of the country through fulfilling local demand and generating foreign exchange through exports.

\section{Limitations}

One of the limitations of this study is that it has only considered a few financial determinants and performed only on the cement sector of PSX. It has not taken into account other factors like investment opportunities, government regulations, and stock exchange regulations to pay the dividend. Only ten years of data from 2009 to 2018 has been analyzed.

\section{Recommendations}

Future studies may include other factors as discussed in the limitations i.e. investment opportunities, government and stock exchange regulations to pay the dividend, sales growth, ownership structure. The beta coefficient may be used to find the impact of risk over DP. Further, future research may be done on all listed firms in the PSX to find the determinants of the listed firms of Pakistan. These results may be compared with other developed, developing and underdeveloped countries results.

\section{References}

1 Ahmed H., Javid A.Y. (2009) Dynamics and determinants of dividend policy in Pakistan (evidence from Karachi stock exchange non-financial listed firms). International Research Journal of Finance and Economics, vol. 25(1), pp. 148-171, https://doi. org/10.5897/JAERD12.088

2 Aivazian V., Booth L., Cleary S. (2003) Do Emerging Market Firms Follow Different Dividend Policies From U.S. Firms? Journal of Financial Research, vol. 26 (3), pp. 371-387, https://doi.org/10.1111/1475-6803.00064

3 Al-Twaijry A.A. (2007) Dividend policy and payout ratio: evidence from the Kuala Lumpur stock exchange. The Journal of Risk Finance, vol. 8(4), pp. 349-363, https://doi.org/10.1108/15265940710777306

4 Ali Khan F., Ahmad N. (2017) Determinants of Dividend Payout: An Empirical Study of Pharmaceutical Companies of Pakistan Stock Exchange (PSX). Journal of Financial Studies \& Research, vol. 16, pp. 1-16, https://doi.org/10.5171/2017.

5 Allen F., Michaely R. (1995) Dividend policy. Handbooks in Operations Research and Management Science. Elsevier, https://doi.org/10.1016/S0927-0507(05)80069-6 
6 Ang J.S. (1982) Do dividends matter? : a review of corporate dividend theories and evidence. New York: Salomon Brothers Center for the Study of Financial Institutions, Graduate School of Business Administration, New York University.

7 Ang J.S. (1998) An Interpretation of the Lintner Dividend Model. Journal of Financial Education, vol. 24, pp. 81-83, https:// doi.org/10.2307/41948284

8 Arif A., Akbar F. (2013) Determinants of Dividend Policy: A Sectoral Analysis from Pakistan. International Journal of Business and Behavioral Sciences, vol. 3(9), pp. 16-33, https://doi.org/10.1016/j.fbr.2017.04.002

9 Asif A., Rasool W., Kamal Y. (2011) Impact of financial leverage on dividend policy: Empirical evidence from Karachi Stock Exchange-listed companies. African Journal of Business Management, vol. 5(4), pp. 1312-1324, https://doi.org/10.5897/ ajbm10.838

10 Baker H.K., Veit E.T., Powell G.E. (2001) Factors Influencing Dividend Policy Decisions of Nasdaq Firms. The Financial Review, vol. 36(3), pp. 19-38, https://doi.org/10.1111/j.1540-6288.2001.tb00018.x

11 Black F. (1976) The Dividend Puzzle. The Journal of Portfolio Management, vol. 2(2), p. 5, https://doi.org/10.3905/ jpm.1976.408558

12 Brav A., Graham J.R., Harvey C.R., Michaely R. (2005) Payout policy in the 21st century. Journal of Financial Economics, vol. 77(3), pp. 483-527, https://doi.org/10.1016/j.jfineco.2004.07.004

13 Crutchley C.E., Hansen R.S. (1989) A Test of the Agency Theory of Managerial Ownership, Corporate Leverage, and Corporate Dividends. Financial Management, vol. 18(4), p. 36, https://doi.org/10.2307/3665795

14 Easterbrook F.H. (1984) Two Agency-Cost Explanations of Dividends Two Agency-Cost Explanations of Dividends. The American Economic Review, vol. 74(4), pp. 650-659, https://doi.org/10.2307/1805130

15 Fama E.F., French K.R. (2001) Disappearing dividends: changing firm characteristics or lower propensity to pay? Journal of Financial Economics, vol. 60(1), pp. 3-43, https://doi.org/10.1016/S0304-405X(01)00038-1

16 Gordon M.J.J. (1963) Optimal Investment and Financing Policy. The Journal of Finance, vol. 50(5), pp. 264-272, https://doi. org/10.1111/j.1540-6261.1963.tb00722.x

17 Haleem F., Javid A.Y. (2011) Modelling dividend behavior in Pakistan. Munich Personal RePEc Archive, p. 20, http:// files/11523/Haleem and Javid - Modeling Dividend Behavior in Pakistan.pdf

18 Ho H. (2003) Dividend policies in Australia and Japan. International Advances in Economic Research, vol. 9(2), pp. 91-100, https://doi.org/10.1007/BF02295710

19 Imran K. (2011) Determinants of Dividend Payout Policy: A Case of Pakistan Engineering Sector. Romanian Economic Journal, vol. 14(41), pp. 47-60.

20 Jabbouri I. (2016) Determinants of corporate dividend policy in emerging markets: Evidence from MENA stock markets. Research in International Business and Finance, vol. 37, pp. 283-298, https://doi.org/10.1016/J.RIBAF.2016.01.018

21 Jensen M.C. (1986) Agency Costs of Free Cash Flow, Corporate Finance, and Takeovers. The American Economic Review, vol. 76(2), pp. 323-329, https://doi.org/10.2307/1818789

22 Kania S.L., Bacon F.W. (2005) What Factors Motivate the Corporate Dividend Decision? American Society of Business and Behavioral Sciences, vol. 1(1), pp. 97-107, https://digitalcommons.longwood.edu/etd/195

23 Khan M.N., Naeem M.U., Salman M. (2016) Factors Affecting the Firm Dividend Policy : An Empirical Evidence from Textile Sector of Pakistan. International Journal of Advanced Scientific Research and Management, vol. 1(5), pp. 144-149.

24 Khan Y., Ali L., Batool S., Ali A. (2017) Growth \&amp; Profitability of Private Commercial Banks: Major Indicator of Its Dividend Policy, http://Www.Sciencepublishinggroup.Com, vol. 2(4), p. 92, https://doi.org/10.11648/J.AJOMIS.20170204.12

25 Lintner J. (1956) Distribution of Incomes of Corporations Among Dividends, Retained Earnings, and Taxes. The American Economic Review, vol. 46(2), pp. 97-113, http://www.jstor.org/stable/1910664

26 Lintner J. (1962) Dividends, Earnings, Leverage, Stock Prices and the Supply of Capital to Corporations. The Review of Economics and Statistics, vol. 44(3), p. 243, https://doi.org/10.2307/1926397

27 Mehta A. (2012) An empirical analysis of determinants of dividend policy-evidence from the UAE companies. Global Review of Accounting and Finance, vol. 3(1), pp. 18-31.

28 Miller M.H., Modigliani F. (1961) Dividend Policy, Growth, and the Valuation of Shares. The Journal of Business, vol. 34(4), p. 411, https://doi.org/10.1086/294442

29 Moradi M., Salehi M., Honarmand S. (2010) Factors affecting dividend policy: Empirical evidence of Iran. Business Excellence, vol. 4(1), p. 45.

30 Nishat M., Bilgrami N. (1994) Who Pays Dividend - An Exploratory Analysis of Firms Listed with Karachi Stock Market. Savings and Development. Giordano Dell-Amore Foundation, https://doi.org/10.2307/25830387

31 Patra T., Poshakwale S., Ow-Yong K. (2012) Determinants of corporate dividend policy in Greece. Applied Financial Economics, vol. 22(13), pp. 1079-1087, https://doi.org/10.1080/09603107.2011.639734

32 Redding L.S. (1997) Firm Size and Dividend Payouts. Journal of Financial Intermediation, vol. 6(3), pp. 224-248, https:// doi.org/10.1006/JFIN.1997.0221

33 Rozeff M.S. (1982) Growth, Beta and Agency Costs As Determinants of Dividend Payout Ratios. Journal of Financial Research, vol. 5(3), pp. 249-259, https://doi.org/10.1111/j.1475-6803.1982.tb00299.x

34 SBP 3rd Quarterly Review 2017-18 (2018) The State of Pakistan's Economy - Third Quarterly Report 2017-2018, http:// www.sbp.org.pk/reports/quarterly/fy18/Third/qtr-index-eng.htm

35 Tahir M., Mushtaq M. (2016) Determinants of Dividend Payout: Evidence from listed Oil and Gas Companies of Pakistan. The Journal of Asian Finance, Economics and Business, vol. 3(4), pp. 25-37, https://doi.org/10.13106/jafeb.2016.vol3.no4.25

36 